\title{
Food Composition Data: Edible Plants from the Amazon
}

\author{
Bernardo Tomchinsky, Gabriela G. Gonçalves, and Almecina B. Ferreira
}

\section{Contents}

1 Edible Amazon. ...................................................... 271

2 Amazonian Fruit Plants..................................................... 274

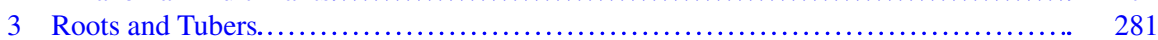

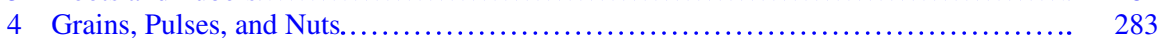

5 Leafy Vegetables......................................................... 285

6 Amazonian Condiment Species.............................................. 286

7 Final Considerations............................................................ 289

References................................................................... 290

\section{Edible Amazon}

The Amazon rainforest comprises a biome with predominantly tropical moist broadleaf vegetation, which occupies the lowlands of the equatorial and humid region of South America. Its 7 million square kilometers are spread over the hydrographic basins of the Amazon, Orinoco, and Araguaia-Tocantins rivers in nine South American countries (Bolivia, Brazil, Colombia, Ecuador, Guyana, French Guiana, Peru, Suriname, Venezuela), of which Brazil holds $60 \%$ of the entire territory (IBGE 2016).

Despite this apparent uniformity, the Amazon rainforest is composed of a mosaic of different types of terrain, vegetation, and ecosystems whose distribution has been altered throughout history according to the Earth's geological and climate changes

\footnotetext{
B. Tomchinsky $(\bowtie)$

Universidade Federal do Sul e Sudeste do Pará, Instituto de Estudos em Saúde e Biologia, Marabá, Pará, Brazil

e-mail: btomchinsky@unifesspa.edu.br

G. G. Gonçalves

Colégio da Villa, Jaguariúna, São Paulo, Brazil
}

\author{
A. B. Ferreira \\ Universidade Federal do Acre, Centro de Ciências Biológicas e da Natureza, \\ Rio Branco, Acre, Brazil \\ e-mail: almecina.ferreira@ufac.br
}


(Prance 1973; Ab'saber 1977; Haffer and Prance 2002). Some of these Amazon landscapes are mountain ranges and mountains, tepuis; aquatic ecosystems; blackwater, whitewater, and transparent rivers of different origins and composition; beaches; islands; archipelagos; flood plains; metalliferous savannas; igapó/várzea (flooded) forests; tropical forests; terra firme forests; capoeira (secondary) forests; Amazonian caatingas; cerrado enclaves; babassu forests; restingas; taquara bamboo forests; and other formations with densely concentrated species (Nelson and Oliveira 2001).

We still know little about the vegetation of the Amazon. Recent studies on the entire Amazonian territory, including Brazil and neighboring countries, list between 11,000 and 14,000 species of known tree plants (Ter Steege et al. 2013; Cardoso et al. 2017), a number close to the 12,000 plants described in the Brazilian Amazon (Flora do Brasil 2020). Hopkins (2017) calculates that we know only $70 \%$ of the 16,000 species that might exist in the biome. Following the current pace of new discoveries of plant species in the biome, it would take at least another 300 years to get to know the entire Amazonian flora (Ter Steege et al. 2016). Just between 2014 and 2015, 216 new plant species were described for science in the biome (WWF 2017). These data are alarming when we consider the current rate of deforestation in the biome and the threats to the survival of traditional peoples and communities, those who hold knowledge about this biodiversity.

Recently, we have better understood of what consists the human (anthropogenic) influence in the formation of the Amazon rainforest. Some works of historical ecology relate the origin of various types of vegetation in the Amazon or the presence and distribution of certain species to the handling of the landscape by indigenous peoples, such as Brazil nut forests, babassu forests, Amazonian dark earth, bamboo forests, and liana shrublands (Balée 1989; Shepard Jr and Ramirez 2011; Clement et al. 2015; McMichael et al. 2013). These studies suggest that between $12 \%$ and $80 \%$ of the entire Amazonian forest could have anthropogenic origin (Balée 1989, 1994; Levis et al. 2017).

From 11,000 years ago, when the oldest known archaeological sites in the Amazon date back to (Roosevelt et al. 1996), the original population spread throughout the Amazon basin forming groups with different cultural practices. This sociobiocultural diversity is expressed in the more than 180 indigenous ethnicities that inhabit the Brazilian Amazon (Heck et al. 2005), without mentioning those that were exterminated in the process of European colonization (Nimuendaju 2017). The reduction of this indigenous population represented the loss of a part of the biodiversity that was in process of domestication, including at least 138 species in different stages of domestication (Clement 1999).

With the beginning of the European colonization, from the sixteenth century on, there was an abrupt rupture in the cultural, social, and environmental dynamics existing in the Amazon with the introduction of exotic species (Crosby 1972) and new cultural practices that were incorporated into the local diet (Cascudo 2011). At the same time, other native species started to have new uses, including as food (Tomchinsky and Ming 2019).

In this process, populations from different parts of the world and from Brazil contributed to the formation of different Amazonian identities, including influences 
from European, African, and Asian populations, as well as other traditional peoples and communities who settled in the region, such as fishermen, riverside dwellers, rubber tappers, Brazil nut pickers, babassu coconut breakers, extractivists, and small farmers among others. Given this complex sociocultural and environmental diversity, it is impossible to identify a single Amazonian dietary culture.

The isolated study of edible plants is not enough to construct an overview on the Amazonian dietary culture, as it is related to other foods of animal and mineral extraction; objects used for farming, hunting, and preparing food; and mythologies, in addition to cultural and social practices. The traditional agricultural system of the Rio Negro, declared a cultural heritage of Brazil, demonstrates how complex these dietary practices are and how they involve several social, cultural, and environmental factors (Emperaire 2010).

For a long time, Amazonian biodiversity has been exploited with an extractive approach, as in the economic cycles of the sertão drugs, or the Brazil nut and rubber trees. These Amazônia was known through a fetishized or exotic lens by the rest of the world through the eyes of the foreign travellers and naturalists. In addition to the domesticated and cultivated Amazon species that have been brought to the rest of the world, many edible Amazon species are used only by local populations and remain unknown to the rest of the world.

Open markets in small and large Amazonian cities are an important showcase to know this edible biodiversity and constitute an important center for agricultural diversity and exchange of germplasm among the local population (Emperaire and Eloy 2008). Some of the most noteworthy markets are the Ver-o-Peso and the market of the 25 de Setembro street in Belém, Pará; the Elias Mansur Market in Rio Branco, Acre; the Adolpho Lisboa Market; the fruit stands near the airport; and the Laranjeiras Market in Manaus, Amazonas, or the weekend fairs in São Gabriel da Cachoeira or Tabatinga, in the state of Amazonas.

The appreciation of traditional food plants or "unconventional food plants" (plantas alimentícias não convencionais, PANC) by the fine cuisine circuit and by movements aimed at valorize sociobiodiversity, such as Slow Food, brought a new stimulus to the study of Amazonian food plants.

However, there is yet much to be studied, considering that between $10 \%$ and $20 \%$ of the world flora has current or potential nutritional use to humans (Kinupp 2007; Kinupp and Lorenzi 2014), which means that, just in the Amazon, from 1.6 to 3.2 thousand plants are edible. Most of the studies carried out in the Amazon region, so far, have been restricted to ethnobotanical research on a specific species, region, or ethnic group, without pursuing research on the nutritional properties and botanical or agronomic aspects. This occur partly due to the bureaucracy for carrying out these researches within the Brazilian legislation (Tomchinsky et al. 2013) but also due to the lack of human and financial resources in research institutions in the northern region of Brazil, in comparison with other regions of the country, or due to the limitations of postgraduate research inside institutional deadlines.

The objective of this chapter is to give an overview on the knowledge about Amazonian edible plants, traditional or unconventional, and general aspects related to them. The species addressed here were separated into groups according to the 
type of dietary use and the part used including fruit species, roots and tubers, grains, pulses and nuts, vegetables, and condiment plants.

\section{Amazonian Fruit Plants}

The Amazon rainforest has a great diversity of edible fruit plants, Cavalcante (1972) lists 163 species and Rabelo (2012) lists at least 250 edible species, many of which known only by the local population, while a few have achieved national or international projection, such as açaí (Euterpe oleracea Mart.), cocoa (Theobroma cacao L.), and cupuassu (Theobroma grandiflorum (Willd. Ex Spreng.) K. Schum.).

Fruit-bearing trees are an important part of the Amazonian nutritional routine (Table 1); several ethnobotanical surveys show that they are by far the most representative group for the local population's diet. In indigenous communities from the Lower Uaupés River region, fruit species represent $78 \%$ of the total food plants cited (Gonçalves 2017). The percentage of fruit species is also large in ethnobotanical listings made with the Yanomami, Sateré-Mawé, and Baniwa indigenous groups who inhabit the Amazon region (Albert and Milliken 2009; Bustamante 2009; Fernandes 2012) (Fig. 1).

Among the fruit trees, some produce small fruits, such as buiuiu or buxixu, which belong to the family Melastomataceae, and are compared to berries. These small fruits do not have a large amount of pulp or high energy value and are consumed as an "appetizer" or as "snacks." They are shrub plants found in capoeiras, on the river banks or streams (Amazonian igarapés), in anthropic areas, or in places with high incidence of light and commonly consumed on the way to the farms or during fishing and hunting, especially by children. Some representatives are buxixuazul (Clidemia japurensis DC.), buxixu (Clidemia hirta (L.) D. Don), and buiuiurosa (Clidemia rubra (Aubl.) Mart.) (Kinupp and Lorenzi 2014; Gonçalves 2017). From the same family, goiaba-de-anta (Bellucia dichotoma Cogn. and Bellucia grossularioides (L.) Triana) is a high tree, appreciated for its fruits by humans and game animals.

In the Western Amazon, from the Rivers Solimões and Negro, it is possible to find in the markets the cubiu or maná-cubiu (Solanum sessiliflorum Dunal.), a cultivated Solanaceae, with fruits that are used in salads, jams, or soft drinks or as a seasoning for dishes, substituting lemon. The fruit has a high content of vitamin $\mathrm{C}$, and its medicinal use in the treatment of diabetes and cholesterol has become widespread (Lorenzi and Matos 2008; Yuyama et al. 2002). Several local ethnovarieties of cubiu are known (Silva Filho et al. 1993). This diversity was studied by Corrado (2018) in the Upper Rio Negro, who reported a total of 22 varieties with specific shapes, sizes, colors, flavors, and uses.

Another interesting Solanaceae is the camapum or gooseberry (Physalis pubescens L.), a spontaneous herbaceous plant that is grown in capoeiras and backyards, with a high content of vitamins and nutrients, but without commercial farming in 


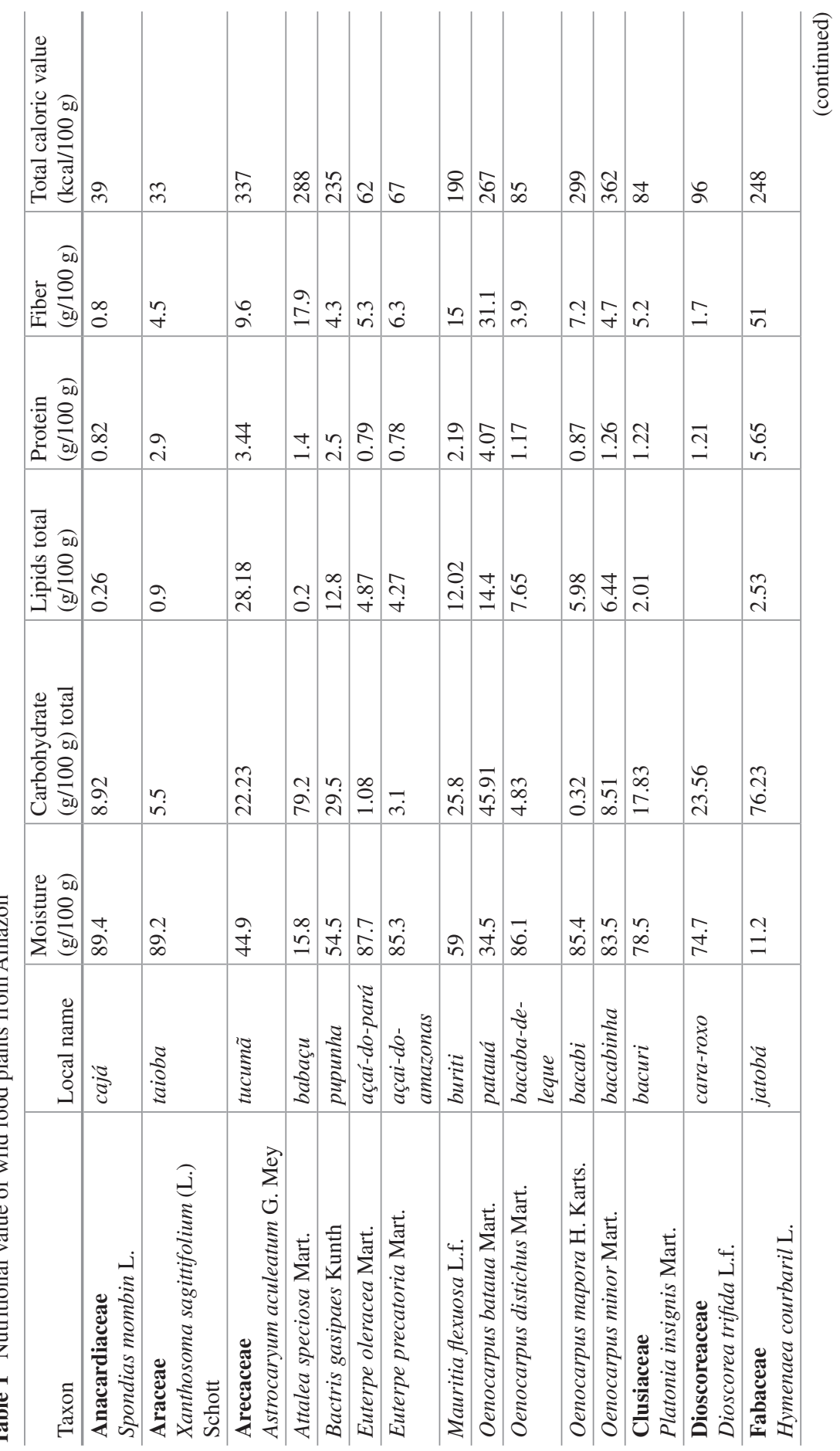




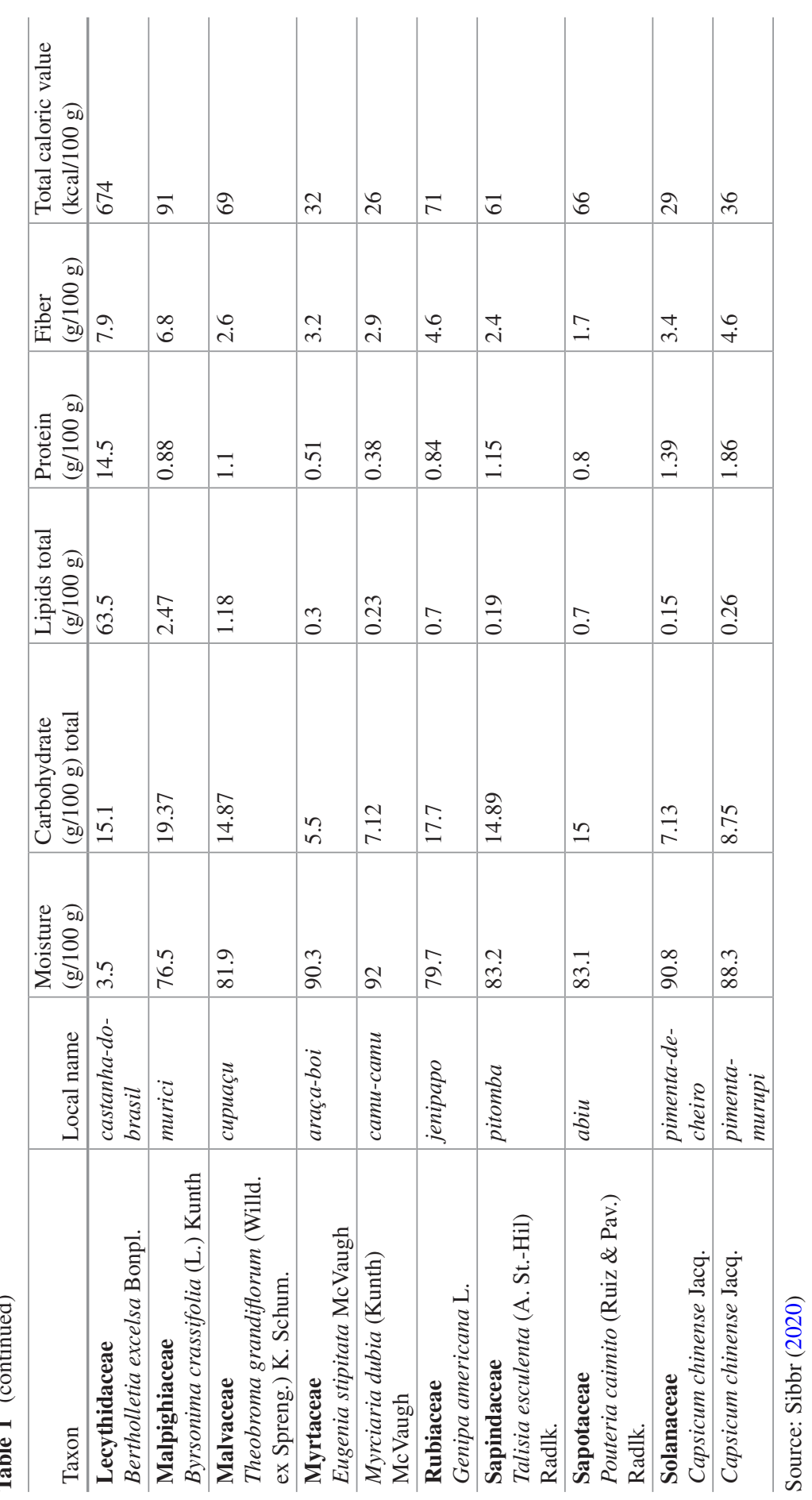




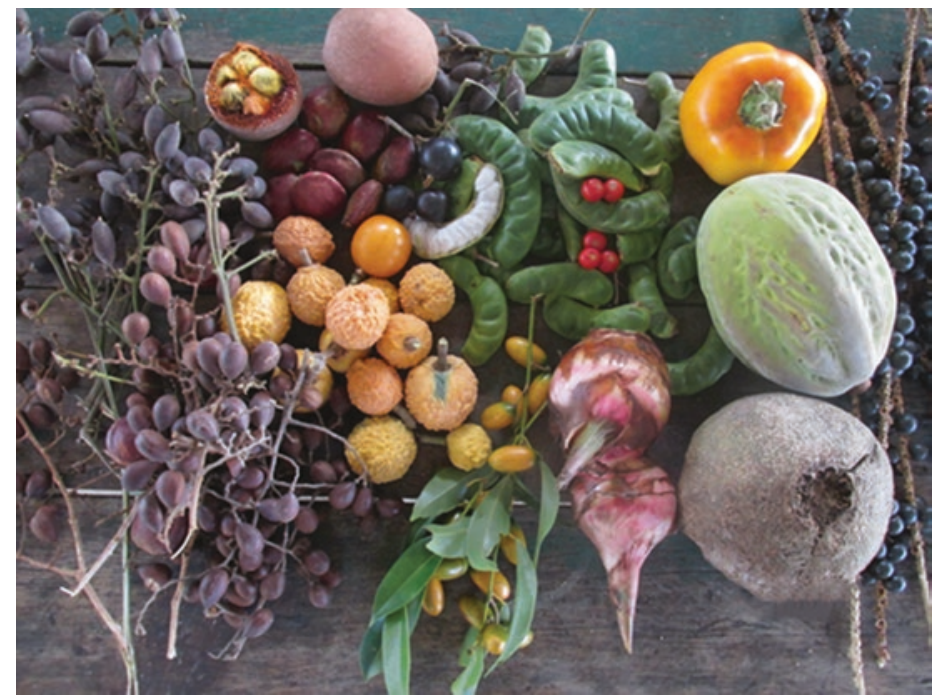

Fig. 1 Edible fruits collected by multiethnic indigenous communities from the Upper Black River. (Source: Gabriela Gonçalves)

Brazil. Despite this, camapum is frequently imported to supermarkets in southeastern Brazil from Colombia, where it is commercially grown (Muniz et al. 2015).

The Myrtaceae family has 266 species in the Brazilian Amazon and produces many small fruits, some of which are edible and nutritious, mainly those from the genera Eugenia, Myrcia, and Psidium (Souza 2015; Flora do Brasil 2020). Some of the species appreciated and cultivated in the Amazon are araçá-boi (Eugenia stipitata McVaugh), goiaba-amarela (Psidium guineense Sw.), araça (Psidium araca Raddi.), pitanga or Brazilian cherry (Eugenia uniflora L.), and guava (Psidium guajava L.).

The species Myrciaria dubia (Kunth) McVaugh, known as camu-camu, azedinha, or caçari, is grown in the Amazon rivers in areas with rocks and is frequently harvested from wild plants but in recent years started to be cultivated and more studied. Due to its high content of ascorbic acid (vitamin C) that reaches up to $3000 \mathrm{mg}$ per $100 \mathrm{~g}$ of fruit, an amount higher than any other known fruit species, industries have given attention to this plant (Yuyama et al. 2002).

One of the main native species of the Amazon and cultivated worldwide is the pineapple (Ananas comosus (L.) Merr.), Bromeliaceae (Clement et al. 2010). Pineapple is an interesting plant because, in addition to its adaptability to Amazonian ecological conditions, it grows in roças (slash and burn farms), backyards, and capoeira shrublands, serving as an important nutritional resource throughout the year. Local varieties of pineapple are poorly studied, but most of them reach a high sugar content, and some are heavier than $15 \mathrm{~kg}$ each, such as those grown in the city of Tarauacá, in Acre State. In the Lower Uaupés River region are grown many varieties with smooth or serrated edge leaves, with distinct leaf colorings and large fruits with high sugar content, such as the abacaxi-aracu (Gonçalves 2017). 
Palm trees (Arecaceae) are abundant in a number of species and frequently in the Amazon region, with multiple registered uses, mainly as food (Henderson et al. 1995; Lorenzi et al. 2004; Clement et al. 2005). This wide presence, associated with the high energy value of its fruits, the absence of anti-nutritional factors, the abundant production of fruit throughout the year, and its palatability, makes palm trees a key group in the diet of the Amazonian population.

The açaí (Euterpe oleracea, Euterpe precatoria Mart., and Euterpe catinga Wallace), the bacaba (Oenocarpus bacaba Mart. and Oenocarpus distichus Mart.), and patauá (Oenocarpus bataua Mart.) are consumed in the form of juice (wine) and are easily found in all markets in the region during the harvest period. A recent work points out that these species are among the hyperdominant plants in the Amazon (Ter Steege et al. 2013), which helps to understand their importance for the local population.

The consumption of açaí is relevant in all Amazon cities. Just the metropolitan region of Belém do Pará is responsible for a daily consumption of 360,000 liters of this fruit's pulp (Oliveira et al. 2002). The açaí pulp has great energy value, mainly from lipids and carbohydrates, and high levels of antioxidants (Santos et al. 2008; Yuyama et al. 2013). The consumption of açaí heart of palm (apical meristem) is more frequent in the Southeast region of Brazil than in the North region, as the local population prefers to consume fruits.

In the eastern Amazon, in a wide transition area into the cerrado and caatinga shrublands, palm forests are frequent, with some palm species common to the different biomes, including babassu-palm (Attalea speciosa Mart.), a species of great cultural importance for the local population and of multiple uses (Araujo et al. 2016). The extractive activity of babassu is dominated by women, currently organized in the Interstate Movement of the Babassu Coconut Gatherers (Movimento Interestadual das Quebradeiras de Coco-Babaçu, MIQCB), in what can be described as a traditional agricultural system. The babassu mesocarp flour and seed oil have a high nutritional value, as well as the coconut beetle larvae (Pachymerus sp., Coleoptera) found in fruits and stipes in decomposition process. Another species common to the palm forests is the inajá (Attalea maripa (Aubl.) Mart.), whose fruits are consumed raw when ripe and boiled in water and from them edible oil can be extracted (Lorenzi et al. 2004).

The tucumã-do-amazonas (Astrocaryum aculeatum G. Mey.) and the tucumã-dopará (Astrocaryum vulgare Mart.), species present in dense or secondary forest, are consumed raw. In the State of Amazonas, the tucumã is the main ingredient of a typical sandwich (x-caboquinho), made with bread or tapioca (manioc flour), cheese, and fried banana. The pulp of $A$. aculeatum fruits has high concentrations of lipids, dietary fiber, potassium, selenium, and beta-carotene (Yuyama et al. 2013). Other species of the genus Astrocaryum also have nutritional use, such as murumuru (Astrocaryum murumuru Mart.), with its fruits consumed raw, and the jauari (Astrocaryum jauari Mart.) from igapó forests, whose fruits are consumed after cooking and its heart of palm is collected for local consumption.

The buriti palm (Mauritia flexuosa L.f.) is grown in clusters in marshy and wet terrain, swampy, or permanently flooded areas. Its fruits are consumed raw, or from 
its pulp, which is rich in carotenoids (Rodriguez-Amaya et al. 2008), a wine or regional sweet can be produced. From its stipe, an edible sap could be extracted, and, in addition, an edible tapioca flour is produced (Correa 1984; Lorenzi et al. 2004).

Among the Amazonian palm trees, one of the few cultivated and domesticated is the peach palm (Bactris gasipaes Kunth), whose pulp, rich in vitamin C and carotenoids, is appreciated by the population after being cooked or as flour in other dishes. Several ethnovarieties of peach palm are known with variation in shape, composition, and color of the fruits and seeds, plant size, and quantity of thorns in the trunks and leaves (Clement and Santos 2002). The farming of peach palm has expanded in Brazil for the extraction of its heart of palm, appreciated in the southeast of the country.

Fabaceae is a pantropical and relevant family in the Amazon, where it is estimated that there are about 2,000 species (Flora do Brasil 2020). The ingas (Inga spp.) are widely distributed in the Amazon, some of which are cultivated, as the ice cream bean (Inga edulis Mart.) and inga assu (Inga cinnamomea Benth.) or spontaneous such as Inga ingoides (Rich.) Willd., Inga laurina (Sw.) Willd, Inga macrophylla Humb. \& Bonpl. ex Willd., and Inga vera Willd.. Out of the ingas, the white aril that surrounds the seeds is edible and appreciated by the population for its sweet flavor but has a low nutritional content (Gonçalves 2017).

The jatobá or jutaí (Hymenaea courbaril L., Fabaceae) is another native Fabaceae, which is appreciated for its farinaceous pulp of strong and peculiar odor and taste, rich in carbohydrates and proteins, consumed raw, or processed as flour for use in breads, cakes, and porridges (Rabelo 2012; Kinupp and Lorenzi 2014).

The Theobroma genus, Malvaceae, is composed of 22 species distributed from the Amazon basin to the south of Mexico, of which cocoa (T. cacao) and cupuassu (T. grandiflorum) have great economic relevance (Garcia et al. 2014). In this genus, almonds are widely used for the production of chocolate and cocoa butter, in addition to the mesocarp in sweets and soft drinks. Other species of the genus are restricted to local use but with great commercial potential such as the mocambo or baraturi (Theobroma bicolor Bonpl.), cupuí (Theobroma subincanum Mart.), cacauí (Theobroma speciosum Willd. Ex. Spreng.), cacau-cabeça-de-urubu (Theobroma obovatum Klotzsch ex Bernoulli), and cacao-cabeça-de-jacaré (Theobroma mariae (Mart.) K. Schum.), which are still poorly studied. Theobromine is the main alkaloid present in cocoa seeds, and among its medicinal effects in humans are the tonic sensation, endorphin and serotonin stimulation, diuretic effect, vasodilator, and the relief of respiratory problems (Peres et al. 2018).

Sapotaceae is an important family in the Amazon, the Pouteria genus being one of the most representative and well-known (Monteiro et al. 2007). The abiu (Pouteria caimito (Ruiz \& Pav.) Radlk. is often grown and sold in Amazonian cities where it is appreciated, despite the latex present in some varieties and in unripe fruits, which coagulates in contact with air, gluing together the lips of whoever eats them (Falcão and Clement 1999).

Of the same genus, the ucuqui (Pouteria ucuqui Pires \& RE Schult.) is a quite peculiar example of fruit consumed by indigenous communities in the Lower Uaupés 
River. According to them, it is only possible to eat the mesocarp of at most two or three untreated fruits, without causing irritation to the oral mucosa; however, when cooked and prepared as porridge, it no longer causes irritation (Gonçalves 2017). The lesions done to the oral mucosa, caused by raw ucuqui, are associated with the presence of calcium oxalate crystals, common in some species of the Sapotaceae family (Monteiro et al. 2007) which is deactivated by cooking.

The genip tree (Genipa americana L.), Rubiaceae, grown in backyards and found in capoeira shrublands and secondary forests, is consumed raw when ripe or in alcoholic beverages. However, the greatest interest by the indigenous population is for its dyeing property, of the genipin pigment of blue-violet color, present in unripe fruits and activated in the presence of oxygen after fruit maceration, used in body painting or as a dye for basketry fibers (Prance 1975).

The biribá or wild sugar apple (Annona mucosa Jacq.) is the main native and cultivated representative of the Annonaceae family in the region. Its fruits weighing up to $1.5 \mathrm{~kg}$ are available in fairs sporadically. Until today, there is no extensive commercial fruit farms developed, despite there being several varieties selected, including some conceived in Florida/the USA (cv. Prolific.) (Lorenzi et al. 2015).

Brazil and Colombia are the diversity centers of the Passifloraceae family, which together concentrate the largest number of Passiflora species in the world (Cervi 1997). The Amazon biome has a large number of passion fruit species that still are little known about their nutritional composition. Despite being potentially edible, few species are actually grown or handled by the population so as to be found in fairs. Among the wild species, picked in capoeira shrublands or as urban weeds, the maracujá-de-cesto (Passiflora foetida L.) is common, and among the plants cultivated most frequently are Passiflora riparia Mart. ex Mast. and Passiflora nitida Kunth. (Gonçalves 2017). In addition to nutritional use, many species are also used in traditional medicine (Lorenzi and Matos 2008).

In the Eastern Amazon, the bacuri (Platonia insignis Mart.), Clusiaceae, is poorly cultivated, despite the high trade value in markets, and is found densely just in certain regions. The pulp of its fruit is very aromatic and used in sweets and beverages and from its seed is extracted a medicinal oil. The fruit has high levels of starch, potassium, phosphorus, and calcium (Carvalho and Nascimento 2018).

Within the different Amazonian ecosystems, the murici (Byrsonima spp.) Malpighiaceae adapts well in open environments and can flourish spontaneously or cultivated. Its small fruits, which vary in color from yellow to red and green, have a characteristic odor and can be stored for a long period in closed bottles filled with water, until consumption, as soft drinks, sweets, with alcoholic beverage, or raw (Cavalcante 1972; Lorenzi et al. 2015).

The cajá ou taperebá (Spondias mombin L.), Anacardiaceae, is a large tree present in the Amazon and the Atlantic Forests, whose fruits are appreciated raw, in juices, sweets, or ice creams. Despite seasonality, the pulp can be frozen for consumption at other times of the year. The huge Amazonian biodiversity can be illustrated by the scientific description of the cajarana (Spondias testudinis J.D. Mitch. \& D.C. Daly) just in 1998, a plant that was known until then only by the local population of Acre (Mitchell and Daly 1998). 
The uva-da-amazônia, cucura, or mapati (Pourouma cecropiifolia Mart.), Urticaceae, is found in the Western Amazon, generally associated with human presence, cultivated or in secondary vegetation. The tasty pulp of its fruits is appreciated for a short period of the year when it is available. Its ingestion can cause irritation in the mouth for some people, due to the rough skin of the epicarp (Lorenzi et al. 2015; Pedrosa et al. 2018).

An important characteristic of Amazonian fruits is the seasonality of each species when they are available in the markets, since most of them are climacteric and hard to store unprocessed. This fact helps to understand why, even in locations far from the largest urban centers, it is easier to find exotic and imported fruits such as orange, pear, or apple than the native ones produced locally.

Despite the immense diversity of edible fruits in the Amazon region, research on them is scarce, mainly related to botanical, agronomical, and biochemical studies. Only the most well-known species such as cocoa, cupuassu, Brazil nut, and açaí have been extensively studied. One of the difficulties regarding the widespread use and cultivation of these plants is that most of them are long-cycle trees and have not been domesticated or are not cultivated.

\section{Roots and Tubers}

Many plants that have edible tuberous organs (roots, tubers, bulbs, rhizomes) are traditionally cultivated by Amazonian peoples. These plants are the basis of the local diet.

Despite the absence of a single Amazonian dietary culture, it is possible to consider that cassava, manioc, or mandioca (Manihot esculenta Crantz) is the main edible species in the region. Mandioca was domesticated in the Madeira River region (Clement et al. 2010) and had its use broadened throughout the entire Amazon and adjacent regions. Cassava is classified into two major groups: mandioca-brava (with a high content of hydrogen cyanide acid) and the mandioca-mansa (with a low content of hydrogen cyanide acid), and in each group, there are hundreds of local ethnovarieties. Its varieties are used in the preparation of at least 14 forms of food and 13 different drinks (Kerr and Clement 1980).

The Upper Rio Negro region and the traditional communities of Acre concentrate a large number of local varieties, mainly mandioca-brava. Emperaire and Peroni (2007) analyzed the case of cassava in the Upper Rio Negro and considered that the agrobiodiversity stems from sociocultural criteria that involve selection, circulation, denomination, and production norms, leading the varieties of plants to be regarded not only as a phylogenetic resource but also as a cultural heritage. Products derived from "harsh" cassava in the Upper Rio Negro constitute a central part of the indigenous diet and culture. Transformation techniques are complex and involve a long operational chain. In this region, more than 70 varieties are grown (Emperaire and Eloy 2008), and the derivative products are very diverse: many 
types of flour, beiju (kind of pancake), porridge, and caxiri (beer), in addition to tapioca, tucupi, and maniçoba (leaves of maniva).

The plants of the Dioscoreaceae family are also of great importance in the diet of the Amazonian peoples. Among the edible and cultivated species of Dioscoreaceae, Dioscorea altíssima Lam., Dioscorea alata L., Dioscorea bulbifera L., and Dioscorea trifida Lf are the most used species and with the largest number of local types, with purple, white, or mixed coloring tubers (Castro et al. 2012). The purple color is due to the presence of anthocyanins with antioxidant action (Kinupp and Lorenzi 2014).

Along with Dioscorea and Manihot, sweet potatoes (Ipomoea batatas (L.) Lam.) are among the most important roots in the regional diet. In addition to the most common commercial cultivars, the Amazonian populations maintain local varieties. This cultivation seems to be particularly important among the Krahô indigenous people, who have an entire cosmology and cultural practices associated with this plant (Lima 2017).

The ariá (Goeppertia allouia (Aubl.) Borchs. \& S. Suárez) is a tuberous species native to the Amazon and traditionally farmed by indigenous and riverside populations in Tropical America. In addition to food, its cultivation is also for the purposes of ornamentation and traditional medicine (Bueno and Weigel 1981). The main feature, which sets it aside from other tuberous species, is that even after cooking, it maintains its crispness quality, rare in other tuberous species.

The species Casimirella rupestris (Ducke) R.A.Howard and Casimirella ampla (Miers) Baehni, Icacinaceae, are endemic to the Amazon and naturally abundant in terra firme forest. Its popular name, mairá potato, derives from Nheengatu and means "liana variety, whose root is edible" (Stradelli 1929; Duno-de-Stefano and Amorim 2015). Its starchy tuberous roots can reach over 200 kilos. Ethnographic studies and traveller's reports highlight the importance of the mairá potato for some indigenous groups in the Amazon in the past. Spruce (1851) reports in his contact with the Tapuya that they consumed it in an identical way to mandioca-brava, extracting the starch and producing flour (Ribeiro 2018). Even with this high productivity, the mairá potato does not currently have significant cultivation among the Amazonian peoples, who show preference for cassava.

In the Lower Uaupés River, a variety of other tuberous species are cultivated besides cassava, such as white yams (Dioscorea spp.), macoari (Heliconia hirsuta Lf), achira or macoari-doce (Canna edulis Ker-Gawl.), sweet potatoes, and some species of Araceae (Xanthosoma spp.) and Marantaceae yai-tutu (Maranta ruiziana Korn), yai-comprido (Maranta arundinacea L.), and aria (G. allouia). The consumption of these roots is mostly after cooking, in porridge, or in the preparation of fermented drinks locally named caxiri (Gonçalves 2017) (Fig. 2).

For the Kaxinawa people in the state of Acre, tuberous species also play an important role in the local diet, especially the taioba (Xanthosoma sagittifolium (L.) Schott), with local types consumed, with different color and flavor: Kixtuku (dark orange), Atsa Yubi (white), Roxo Yubi (orange with purple edges), Kapa Nawa (light orange), Kapa Yubi (light orange with white edges), and Maspa Yubi (light orange with green edges). All tubers have, aside from color, different shapes. 


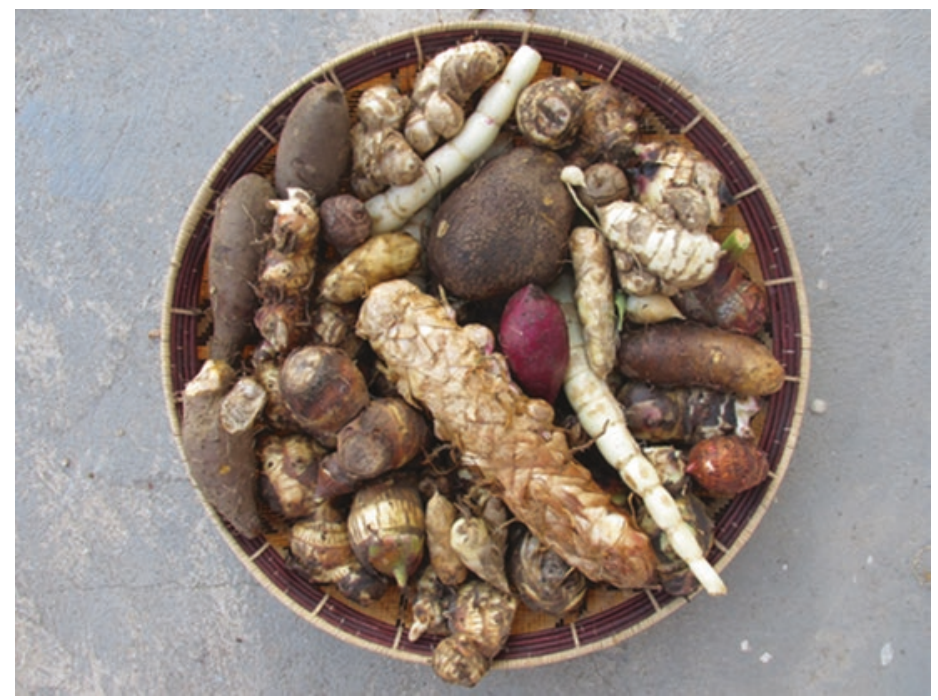

Fig. 2 Edible roots and tubers cultivated by multiethnic indigenous communities from the Upper Black River. (Source: Gabriela Gonçalves)

The production of tuberous edible plants can be carried out throughout the year in the Amazon. Plants can be left intact in the field for a long period, and the roots are harvested gradually, as needed, unlike grains and pulses, which are farmed more commonly in temperate regions. This is an important strategy for traditional populations in the tropics, in response to the problems of sazonality and storing other foods in hot and humid climate (Martins 2005).

Unlike fruit species, which are grown in backyards or picked in the forest, family farms are the place where the cultivation of tuberous plants predominates. For many of the indigenous peoples of the Amazon, these farms and the plants grown in them are usually the domain of women, whereas forests and rivers are male domains.

\section{Grains, Pulses, and Nuts}

With regard to carbohydrate intake, some grains and seeds have taken on an important role regionally, along with tuberous roots, with emphasis on cultivated and domesticated species.

Maize (Zea mays L.), native to Central America, has been cultivated in the Amazon for more than 8000 years (Bush et al. 1989), a period before agriculture had even spread in the region (Clement et al. 2015). During this period, it was selected and domesticated again in the region (Kistler et al. 2018). Traditional corn grown by the indigenous peoples of the Amazon has farinaceous endosperm (soft corn) as oppose to hard and crystalline, like most commercial cultivars. There is a 
large number of cultivated maize ethnovarieties, each with specific uses by certain populations (Teixeira and Landau 2016). The cultural importance of corn is evident in the mythology of several indigenous peoples where it is present; in festive food preparations, such as caxiri; and in traditional festivals (Pereira 1974).

The Kaxinawa of Acre cultivate two important ethnovarieties of corn for the community's diet, classified as "Nawa Sheki" and "Sheki Kui," varying in orange, dark red, yellow, and whitish colors, which are used to make porridge and different types of cakes.

The peanut or groundnut (Arachis hypogaea L.) is another important source of carbohydrates and lipids often cultivated by various indigenous peoples of the Amazon. The Kawabi, from Xingu, have more than 14 ethnovarieties of this species, each with different characteristics and uses (Suassuna et al. 2016). Among the Kaxinawá, the peanut is known as tama, where there are six ethnovarieties of different colors.

Beans (Phaseolus vulgaris L., Phaseolus lunatus L., and Vigna unguiculata (L.) Walp.) are grown in floodplains or in terra firme and are among the most important plants for the local population. The "muffled" is a specific system for the culture of beans, where the capoeira shrub is cut down so that the branches may provide support for the growth of the climbing varieties (Sivieiro et al. 2016). The local varieties are quite diverse, such as the purple and butter beans, common in the state of Pará, or the red gorgutuba, red Peruvian, rosinha, quarantão, manteiga-roxo, and arigozinho in Acre.

Currently, rice (Oryza sativa L.) has become a species of regional importance, being grown in large areas in the process of pasture formation or by small farmers and indigenous peoples. Among the Krahô, 26 cultivated rice ethnovarieties were identified (Rangel and Dias 2016). Studies indicate that there were species of Oryza native to Brazil that was in the process of domestication by indigenous populations (Hilbert et al. 2019). In the Rio Negro, some riverside and indigenous populations still collect seeds of Oryza latifolia Desv. for their own consumption.

Economically, castanha-do-Brasil, Brazil nut, or Amazon nut (Bertholletia excelsa Bonpl.), Lecythidaceae, has had great national relevance since the nineteenth century, when Brazil nut pickers moved in the region during the harvest season. In addition to the caloric potential, studies show that Brazil nuts have high selenium content, an important element in disease prevention. Although Brazil has large areas of Brazil nut forests, associated with human activity in domesticating the landscape (Shepard Jr and Ramirez 2011) in regions such as Acre and Southeast Pará, deforestation has made Bolivia the world's largest exporter of Brazil nut (Homma 2000; Shanley et al. 2010). Considering the long reproductive cycle of the Brazil nut tree, studies have successfully enabled the commercial cultivation of selected plants and the use of techniques that reduce the time for fruiting juvenility in young plants.

The sapucaia (Lecythis Pisonis Cambess.), another species of Lecythidaceae, is consumed by the local population. Its dehiscent capsule fruit opens when riped and the seeds fallen on the ground, where the local fauna appreciated it (Mori and Prance 1981). 
Guarana (Paullinia cupana Kunth., Sapindaceae) is a shrubby climbing plant, whose cultivation technique and selection and domestication process were carried out by the Mawé indigenous people, where it is present in mythology and festivities. Despite having its use more closely related to medicinal properties due to the high content of caffeine and other substances, currently its commercial cultivation is done on a large scale for the production of medicines and soft drinks for the industry (Tricaud et al. 2016).

In spite of the relatively low number of species that provide seeds and grains for the Amazonian population's diet, they have considerable regional importance, given the large volume consumed, the cultivated area, the nutritional aspects, and the existence of a large number of ethnovarieties and species handled or domesticated. This importance is also made evident by the presence of these plants in the mythology and culture of some indigenous peoples.

\section{$5 \quad$ Leafy Vegetables}

The habit of consuming leafy vegetables is not very common among the Amazonian population, especially among indigenous peoples (Katz et al. 2012). Alves da Silva (1962) observes in the Upper Rio Negro that "If the indigenous diet lacks vegetables and legumes, many are the fruits they consume." It is likely that the possible lack of vitamins and minerals, which could be caused by the low consumption of leafy vegetables, is supplemented by the large number of fruit species consumed by the local population (Katz et al. 2012).

Of the native vegetables, one of the foremost is the jambu (Acmella oleracea (L.) R.K. Jansen), which can also be classified as spice or medicinal. Jambu plant leaves are often used sautéed in traditional recipes such as duck in tucupi sauce and tacacá. Due to its local importance, there are many studies carried out with this species and even varieties improved available for the farmers (Cardoso 1997; Kinupp and Lorenzi 2014).

Some leafy vegetables available in the region are potentially toxic and need to be cooked for a long time as to lose this toxicity. Cassava leaves (M. esculenta), known as maniçoba, have a high level of hydrogen cyanide acid and are traditionally cooked for 7 days, before being used in festive dishes. Caruru leaves (Phytolacca rivinoides Kunth \& C.D.Bouché), of more restricted use in the Upper Rio Negro, are consumed only after cooking along with fish or quarry broths (Gonçalves 2017).

The cipó-kupá (Cissus gongylodes (Baker) Burch. Ex Baker, Vitaceae) is one of the rare horticultural species that have been selected by indigenous populations and is cultivated to this day among Kayapós and Timbira groups. The plant has a climbing habit, and its succulent steam is used in broths or roasts, after the use of temperature to reduce the action of the calcium oxalate it has (Kerr et al. 1978; Dias et al. 2016). 
Taioba (Xanthosoma spp.), Araceae, cultivated for its tubers roots, is another important native vegetable whose leaves are appreciated after cooking to reduce calcium oxalate (Cardoso 1997, Kinupp and Lorenzi 2014).

The contribution of migrant populations to the consumption of vegetables in the Amazon is remarkable. The habit of consuming okra (Hibiscus esculentus L.), cuxá (Hibiscus sabdariffa L.), caruru (Talinum paniculatum Jacq-Gaertn), and junça (Cyperus esculentus L.) in the eastern Amazon is influenced by African populations of the states of the Pará and Maranhão (Cardoso 1997). Asian immigrants were important for the development of modern horticulture in the Amazon, with techniques for the cultivation of conventional vegetables such as lettuce (Lactuca sativa L., Asteraceae) and black pepper (Piper nigrum L., Piperaceae) (Homma 2009). In addition to these plants, it is common to cultivate exotic vegetables in backyards and jiraus (suspended location) in the region, such as pumpkin (Cucurbita spp.), cowpea (Vigna unguiculata (L.) Walp.), and kale (Brassica oleracea var. Acephala DC.) (Cardoso 1997).

The attempt to grow tomatoes, bell peppers, or other conventional farm vegetables has not been successful in the region due to the lack of cultivars adapted to local climatic conditions, difficulty in producing seeds or propagules by the farmers themselves, or cultivars resistant to fungal diseases that increase with the high temperature and humidity of the region. Kinupp and Lorenzi (2014) address other native species that could be used as farm vegetables in the region, such as caapeba (Piper peltatum L.), picão (Bidens spp.), and other spontaneous ones, but which are neglected by or unknown to most of the population.

\section{Amazonian Condiment Species}

Spice plants are those that, when added in small quantities in food preparation, have the capacity to modify the perception we have of them (Tomchinsky 2017). They are species that, for the most part, have a high concentration of secondary compounds in their composition such as terpenes, alkaloids, and phenols (Lorenzi and Matos 2008; Simões et al. 2017).

Due to the high concentration of these secondary compounds, many of these plants have multiple uses, such as medicinal, entheogenic, or aphrodisiac (Schultes and Hofmann 2001; Lorenzi and Matos 2008; Ratsch 2011). However, for this same reason, the ingestion of high doses of some condiments may be potentially toxic to humans, such as the myristic acid in the nutmeg (Schultes and Hofmann 2001), coumarin in the cumaru (Lake 1999), piperine in the black pepper, and capsaicin in Capsicum peppers (Lorenzi and Matos 2008). The use of condiments is also important for food preservation, whether because of its antimicrobial action (Ethurk 2008; Liu et al. 2017) or in overlapping undesired traits in degraded foods.

The Amazonian culture, of indigenous origin, has adopted as its main condiment the hot peppers of the Capsicum genus. There are indications that Capsicum chinense Jacq. was domesticated in the Amazon region more than 4000 years ago 
(Clement et al. 2010). Among the dozens of types of hot peppers grown in the region, the most common are locally known as murupi, pimenta-de-cheiro, pimentabode, cumari-do-pará and biquinho (C. chinense), tabasco (Capsicum frutescens L.), and dedo-de-moça and cumari (Capsicum baccatum L.) (Carvalho et al. 2006; Nascimento Filho et al. 2007; Ribeiro et al. 2008; Roman et al. 2000).

In the Upper Rio Negro, the consumption of peppers seems to be even more appreciated than in other regions by the local and predominantly indigenous population. The quinhapira, a fish stew typical of the region, is made with a large quantity of hot peppers. In this region, the production technique of the jiquitaia or the baniwa peppers is preserved, which mixes up to 78 ethnovarieties of peppers that are dried, smoked (roasted), grinded, and added to salt (Silva et al. 2016).

Salt was difficult to obtain in the pre-Columbian Amazon, when compared to other coastal locations, and was obtained just through trade with other distant regions or derived from vegetables. These vegetable salts have potassium cation $(\mathrm{KCl})$, while those of marine origin have sodium cation $(\mathrm{NaCl})$. They are obtained through the process of pyrolysis of certain species of plants, mainly from the families Arecaceae, Amaranthaceae, and Lecythidaceae. This process has been described among several Amazonian ethnic groups such as the Waimiri-Atroari, Witoto, Yanomami, and Tupinambá (Martius 1979; Bastos 1987; Albert and Milliken 2009; Tomchinsky 2017; Kermath et al. 2020).

The cassava (M. esculenta), a central species in the Amazon diet, is also a source of tucupi, an edible yellow broth, but potentially toxic due to its high concentration of cyanide, extracted during the production of the flour. After boiled and/or fermented and purified, the tucupi broth is used in the preparation of various Amazonian dishes such as tacacá and duck in tucupi sauce, topped on pepper sauces. When refined and reduced, it has the appearance of a smoked sweet molasses, black in color, known as black tucupi, which is used as a spice, with peppers and citrus-like ants (Atta sexdens rubropilosa Forel 1908) (Brazi 2013).

The first reports about annatto (Bixa orellana L.) describe its medicinal use or its use in body painting (Tomchinsky and Ming 2019). Currently, it is widely used as a red or yellow food dye in homemade and industrialized products (dye code E-160b) due to carotenoids bixin (fat-soluble) and norbixin (water-soluble) extracted from the aril of its seeds, which also have antioxidant action for food preservation (Garcia et al. 2012).

The jambu (A. oleracea), also cited as horticultural, can be considered to be a condiment for the anesthetic effect caused by its inflorescences, rich in spilanthol terpene, when consumed in broths, stews, or the infusion of alcoholic beverages (Cardoso 1997; Lorenzi and Matos 2008; Barbosa et al. 2016).

The chicória-do Pará (Eryngium foetidum L.) is a biannual herbaceous cultivated and registered as one of the first species native to Brazil for use in spices (Tomchinsky and Ming 2019). The eryngial terpene is predominant in the composition of its essential oil, which has aromatic properties similar to that of the coriander (Coriandrum sativum L.) (Paul et al. 2011; Kinupp and Lorenzi 2014).

Other exotic and more conventional species are frequent in Amazonian cuisines and grown in backyards or found in markets such as chives (Allium shoenoprasum 
L.), turmeric (Curcuma longa L.), parsley (Petrosilum crispum (Mill.) Fuss), citrus plants (Citrus spp.), clove basil (Ocimum gratissimum L.), coriander (Coriandrum sativum L.), black pepper (Piper nigrum L.), cumin (Cuminum cyminum L.), onion (Allium cepa L.), and garlic (Allium sativum L.). Although exotic, these plants were incorporated centuries ago in the diet of the local population and in their pharmacopoeia and are of daily use by the entire Amazonian population.

Given the Amazonian biodiversity, the absence of more native species with widespread condiment use in the region is surprising. Some native plants have their use restricted to a certain region, such as japura (Erisma japura Spruce ex Warm.) in the Upper Rio Negro, whose fermented fruit is used to season fish (Ribeiro 1995; Gonçalves 2017); others have been studied as substitutes for the most frequently used spices or within a new proposal of fine cuisine that looks for "novelties" within the "exotic" Amazonian biodiversity.

The various species of the genus Xylopia (X. aromatica (Lam.) Mart., X. benthamii REFr., $X$. frutescens Aubl., and $X$. sericea A.St.-Hil.) are popularly known as pimenta-de-macaco or pindaíba, and its dried fruits have aromatic compounds used for food and in alcoholic infusions as "drink seasoning" and as medicine by the local population (Lorenzi and Matos 2008; Silva et al. 2015).

The canela-preciosa (A. canelilla), a large Lauraceae used as a medicine and for timber, has a characteristic odor that may be a substitute for the cinnamon plants (Cinnamomum burmannii (Nees \& T. Nees) Blume, C. verum J. Presl, and C. cassia (L.) J.Presl.). Its essential oil is concentrated in vessels at the heartwood and in a lower concentration in the leaves, with a predominance of the compound 1-nitro-2phenylethane responsible for its characteristic aroma (Lorenzi and Matos 2008; Kinupp and Lorenzi 2014).

The cumaru or tonka bean (D. odorata), a large Fabaceae, has seeds rich in coumarin with multiple uses (cosmetics and perfumery, tobacco fragrance, medicinal, rodenticide), as well as timber. The consumption of cumaru illustrates the discussion about the safe dosage of condiment species, since this plant had its use restricted in the USA and Europe due to the coumarin's carcinogenic and hepatotoxic potential (Carvalho 2009; Rego et al. 2017).

The indiscriminate exploitation of pau-cravo (Dicypellium caryophyllaceum (Mart.) Nees) (Lauraceae), a species with high content of eugenol, the same compound found in the clove (Syzygium aromaticum), for timber and medicinal use, almost brought this species to extinction, being currently found only in small areas and critically endangered (CR) (CNCFlora 2020). Pau-cravo's endangered case raises the question of how important it is to study more about the management of native non-cultivated species of the Amazon, before using them.

Several species of genus Vanilla (Orchidaceae) native to the Amazon (V. appendiculata Rolfe, V. gardneri Rolfe, V. mexicana Mill., V. palmarum (Salz. Ex Lincl.) Lindl., V. planifolia Jacks. Ex Andrews, Vanilla pompona Schiede) have a high content of vanillin in their seeds and beans and can be used in gastronomy safely. Considering the little knowledge about some of these species and their rarity in nature, several studies would be necessary to enable their sustainable exploitation or 
cultivation in agroforestry systems, since they are epiphytic plants with a long flowering and fruiting cycles.

The leaves of the garlic vine (Mansoa alliaceae (Lam.) A.H. Gentry) are occasionally used as a condiment to replace the common garlic, in addition to various registered medicinal uses (Lorenzi and Matos 2008). The sulfurous compounds alliin and allyl sulfides in its leaves give it its characteristic odor.

Recently, the priprioca or jointed flatsedge (Cyperus articulatus L.), an herb native to Africa and naturalized in the Amazon for medicinal and ritualistic uses, is being used as a dessert fragrance in fine cuisine restaurants (Trajano 2008).

Aiming to expand the definition of condiment adopted in this chapter, we can cite the various species that provide edible oil present in the region, with emphasis on the Arecaceae and Fabaceae families (Lorenzi et al. 2004; Tomchinsky 2017) or the numerous pulp fruits with high degrees brix that can be fermented and acetified to use as vinegar and acidifier.

Other native species of the Amazonian flora have great potential for use as spices, but they should be better studied regarding their phytochemical composition, safety of use, handling, and cultivation before their use becomes widespread. Of 923 plant species with records of condiment use present in Brazil, among native (501) and exotic (422), 343 are present in the Amazon region, including plants with records of use as aromatic, flavoring, coloring, source of vegetable salt, sweetener, edible oil, acidifier, edible gums and resins, meat tenderizer, or food wrapping; as a substitute for hop, coffee, cocoa, and vanilla; for aromatic infusions; or as "spice for alcoholic beverages" (Tomchinsky 2017).

\section{Final Considerations}

This chapter provides a brief overview on the knowledge about Amazonian edible plants, traditional or unconventional, and general aspects related to them, but does not take the topic to exhaustion. The Amazon has a rich food biodiversity, and among the different food groups, fruits, grains, and tubers are the most important in the diet of the Amazonian population. We can verify that among the cultivated plants, there is a great amount of ethnovarieties maintained by the local populations. It is worrisome that all this sociobiodiversity is threatened by the deforestation of the biome and by other threats to traditional peoples and communities that hold the knowledge on the use of these plants. Finally, most of this biodiversity has been poorly studied, mainly in relation to botanical, agronomic, and phytochemical aspects. This lack of knowledge is due, in part, to the few number of institutions and researchers dedicated to these studies in Amazon, in relation to its size. 


\section{References}

Ab'Saber NA (1977) Espaços ocupados pela expansão dos climas secos na América do Sul, por ocasião dos períodos glaciais quaternários. Paléo 3:1-19

Albert B, Milliken W (2009) Urihi A: a terra-floresta Yanomami. Socioambiental/IRD, São Paulo/ Paris

Alves da Silva ABA (1962) A civilização indigena do Uaupés. Missão Salesiana do Rio Negro, São Paulo

Araujo FR, Gonzalez-Perez SE, Lopes MA, Viegas IJM (2016) Ethnobotany of babassu palm (Attalea speciosa Mart.) in the Tucuruí Lake Protected Areas Mosaic - Eastern Amazon. Acta Bot Bras 30(2):193-204. https://doi.org/10.1590/0102-33062015abb0290

Balée W (1989) Cultura vegetal da Amazônia brasileira. In: Neves WA (ed) Biologia e ecologia Humana na Amazônia: avaliação e perspectivas. Museu Paraense Emílio Goeldi, Belem, pp 95-110

Balée W (1994) Footprints of the forest: Ka'apor ethnobotany: the historical ecology plant utilization by an amazon people. Columbia University Press, New York

Barbosa AF, Carvalho MG, Smit RE et al (2016) Spilanthol: occurrence, extraction, chemistry and biological activities. Rev Bras 26(1):128-113. https://doi.org/10.1016/j.bjp.2015.07.024

Bastos A (1987) A pantofagia ou as entranhas práticas alimentares na selva. Editora nacional, São Paulo

Brazi D (2013) Cozinha Tradicional Amazônica. Editora Bei, São Paulo

Bueno CR, Weigel P (1981) Brotação e desenvolvimento inicial de rizomas de Ariá (Calathea allouia (Aubl.) Lindl.). Acta Amazon 11(2):407-410. https://doi.org/10.1590/1809-43921981112408

Bush MB, Piperno DR, Colinvaux PA (1989) A 6000 year history of Amazonia maize cultivation. Nature 340:303-305. https://doi.org/10.1038/340303a0

Bustamante GGF (2009) Frutos, sementes e órgãos tuberosos na alimentação da etnia SateréMawé dos Rios Marau e Urupadi (Maués-Amazonas). Dissertation, Faculdade de Ciências Agronômicas, Universidade Federal do Amazonas

Cardoso MO (1997) Hortaliças não convencionais da Amazônia. Embrapa, Brasília

Cardoso D, Sarkinem T, Alexander S et al (2017) Amazon plant diversity revealed by a taxonomically verified species list. PNAS 114(40):10695-10700. https://doi.org/10.1073/ pnas. 1706756114

Carvalho PER (2009) Cumaru-ferro Dipteryx odorata. Comunicado Técnico 225. Embrapa, Colombo

Carvalho JEU, Nascimento WMO (2018) BACURI: Platonia insignis. Instituto Interamericano de Cooperación para la Agricultura, Costa Rica

Carvalho SIC, Bianchetti LB, Ribeiro CSC, LopesS CA (2006) Pimentas do gênero Capsicum no Brasil. Documento 94. Embrapa hortaliças, Brasília

Cascudo LC (2011) História da alimentação no Brasil, 4th edn. Global, São Paulo

Castro AP, Fraze TJP, Pereira HS et al (2012) Etnobotânica das variedades locais do cará (Dioscorea spp.) cultivados em comunidades no município de Caapiranga, estado do Amazonas. Acta Bot Bras 26(3):658-667. https://doi.org/10.1590/S0102-33062012000300015

Cavalcante PB (1972) Frutas comestíveis da Amazônia. Museu Paraense Emília Goeldi, Belem

Cervi AC (1997) Passifloraceae do Brasil: estudo do gênero Passiflora L., subgênero Passiflora. Fontqueria, Madrid

Clement CR (1999) 1492 and the loss of Amazonian crop genetic resources. I. The relation between domestication and human population decline. Econ Bot 53(2):188-202. https://doi. org/10.1007/BF02866498

Clement CR, Santos LA (2002) Pupunha no mercado de Manaus: Preferências de consumidores e suas implicações. Rev Bras Frutic 24(3):778-779. https://doi.org/10.1590/ S0100-29452002000300055

Clement CR, Lleras E, Leeuwen JV (2005) O potencial das palmeiras tropicais no Brasil: Acertos e fracassos das últimas décadas. Agrociencia 9(1-2):67-71 
Clement CR, Cristo-Araújo M, Coppens GD et al (2010) Origin and domestication of native Amazonian crops. Diversity 2:72-106. https://doi.org/10.3390/d2010072

Clement CR, Denevan WM, Heckenberger MJ et al (2015) Domestication of Amazonia before European conquest. Proc R Soc B 282(20150813):1-9. https://doi.org/10.1098/rspb.2015.0813

CNCFLORA (2020) Dicypellium caryophyllaceum in Lista Vermelha da flora brasileira versão 2012.2 Centro Nacional de Conservação da Flora. Available in http://cncflora.jbrj.gov.br/portal/pt-br/profile/Dicypelliumcaryophyllaceum. Accessed 3 Sept 2020

Corrado AR (2018) Diversidade cultural e genética de solanum sessiliflorum Dunal na Amazônia Brasileira. Dissertation, Faculdade de Ciências Agronômicas, Universidade Estadual Paulista

Correa MP (1984) Dicionário das plantas uteis do Brasil e das exóticas cultivadas. MINAGRI, Rio de Janeiro

Crosby AW (1972) The Columbian exchange: biological and cultural consequences of 1492 . Greenwood Press, Westpost

Dias T et al (2016) Cupá, uma cultura alimentar indígena pré-colombiana: relatos de reintrodução. In: Dias T, Edit JS, Udry C (eds) Diálogos de saberes - relatos da Embrapa. Coleção povos e comunidades tradicionais, vol 2. Embrapa, Brasília, pp 73-85

Duno-de-Stefano R, Amorim B (2015) Icacinaceae in Lista de Espécies da Flora do Brasil. Jardim Botânico do Rio de Janeiro. http://floradobrasil.jbrj.gov.br/jabot/FichaPublicaTaxonUC/ FichaPublicaTaxonUC.do?id=FB84145. Accessed 03 Oct 2020

Emperaire L (2010) Dossiê de registro: o sistema agrícola tradicional do Rio Negro. Associação das comunidades indígenas do Médio Rio Negro, Brasília

Emperaire L, Eloy L (2008) A cidade, um foco de diversidade agrícola no Rio Negro (Amazonas, Brasil) ?. Boletim do Museu Paraense Emílio Goeldi. Ciências Humanas 3:195-211. https:// doi.org/10.1590/S1981-81222008000200005

Emperaire L, Peroni N (2007) Traditional management of agrobiodiversity in Brazil: a case study of manioc. Hum Ecol 35(2):761-768. https://doi.org/10.1007/s10745-007-9121-x

Ethurk O (2008) Antibacterial and antifungal activity of ethanolic extracts from eleven spice plants. Biologia 61(3):275-278. https://doi.org/10.2478/s11756-006-0050-8

Falcão MA, Clement CR (1999) Fenologia e produtividade do abiu (Pouteria caimito) na Amazônia Central. Acta Amazon 29(1):3-1. https://doi.org/10.1590/1809-43921999291011

Fernandes RS (2012) Frutos, sementes e amêndoas silvestres alimentícias na comunidade indígena Tunuì-Cachoeira-AM. 2012. Dissertation, Faculdade de Ciências Agronômicas, Universidade Federal de Lavras

Flora do Brasil 2020 (2020) Jardim Botânico do Rio de Janeiro. Available in http://www.floradobrasil.jbrj.br. Accessed in 01 Oct 2020

Garcia CER et al (2012) Carotenoides bixina e norbixina extraídos do urucum (Bixa orellana L.) como antioxidantes em produtos cárneos. Ciência Rural 42(8):1510-1517. https://doi. org/10.1590/S0103-84782012000800029

Garcia TB et al (2014) Leaf anatomical features of three Theobroma species (Malvaceae) native to the Brazilian Amazon. Acta Amazon 44(3):291-300. https://doi. org/10.1590/1809-4392201300653

Gonçalves GG (2017) Etnobotânica de plantas alimentícias em comunidades indígenas multiétnicas do Baixo Rio Uaupés - Amazonas. Dissertation, Faculdade de Ciências Agronômicas, Universidade Estadual Paulista

Haffer J, Prance GT (2002) Impulsos climáticos da evolução na Amazônia durante o Cenozóico: sobre a teoria dos Refúgios da diferenciação biótica. Estudos avançados 16(46):175-206. https://doi.org/10.1590/S0103-40142002000300014

Heck ECK, Loebens F, Carvalho PD (2005) Amazônia indígena: conquistas e desafios. Estudos avançados 19(53):237-255. https://doi.org/10.1590/S0103-40142005000100015

Henderson A, Galeano G, Bernal R (1995) Field guide to the palms of the Americas. Pinceton University Press, Princeton

Hilbert L, Neves EG, Pugliese F et al (2019) Evidence for mid-Holocene rice domestication in the Americas. Nat Ecol Evol 1(11):1693-1698. https://doi.org/10.1038/s41559-017-0322-4 
Homma AKO (2000) Cronologia da ocupação e destruição dos castanhais no Sudeste paraense. Embrapa Amazônia Oriental, Belém

Homma AKO (2009) Os japoneses na Amazônia e sua contribuição ao desenvolvimento agrícola. Somanlu 9(1):113-113

Hopkins MJ (2017) Modelling the known and unknown plant biodiversity of the Amazon Basin. J Biogeogr 34(8):1400-1411. https://doi.org/10.1111/j.1365-2699.2007.01737.x

IBGE (2016) Manual Técnico da Vegetação Brasileira. Manuais técnicos em Geociências. IBGE, Brasília

Katz E, Léopez CL, Fleury M et al (2012) No greens in the forest? Note on the limited consumption of greens in the amazon. Acta Soc Bot Pol 81:283-293. https://doi.org/10.5586/asbp.2012.048

Kermath BM, Bennet BC, Pulsipher LM (2020) Food plants in the Americas: a survey of the domesticated, cultivated and wild plants used for human food in North, Central and South America and the Caribbean. https://www.academia.edu/1139225/Food_Plants_in_the_ Americas_A_Survey_of_the_Domesticated_Cultivated_and_Wild_Plants_Used_for_Human_ Food_in_North_Central_and_South_America_and_the_Caribbean. Accessed 14 Sept 2020

Kerr WE, Clement CR (1980) Práticas agrícolas de consequências genéticas que possibilitaram aos índios da Amazônia uma melhor adaptação às condições ecológicas da região. Acta Amazon 10(2):251-226. https://doi.org/10.1590/1809-43921980102251

Kerr WE, Posey DA, Wolter Filho W (1978) Cupá, ou cipó-babão, alimento de alguns índios amazônicos. Acta Amazon 8(4):702-705. https://doi.org/10.1590/1809-43921978084702

Kinupp VF (2007) Riqueza de plantas alimentícias não-convencionais na região metropolitana de Porto Alegre. In: Plantas alimentícias não-convencionais da Região Metropolitana de Porto Alegre, RS. Porto Alegre. Dissertation, Faculdade Agronomia, Universidade Federal do Rio Grande do Sul

Kinupp VF, Lorenzi H (2014) Plantas alimentícias não convencionais (PANC) no Brasil: guia de identificação, aspectos nutricionais e receitas ilustradas. Instituto Plantarum, São Paulo

Kistler L, Maezumi SY, Souza JG (2018) Multiproxy evidence highlights a complex evolutionary legacy of maize in South America. Science 362(6420):1309-1313. https://doi.org/10.1126/science.aav0207

Lake BG (1999) Coumarin metabolism, toxicity and carcinogenicity: relevance for human risk assessment. Food Chem Toxicol 37(3):423-453. https://doi.org/10.1016/ s0278-6915(99)00010-1

Levis C, Costa FRC, Peña-Claros M (2017) Persistent effect of pre-columbian plant domestication on Amazon. Science 355(6328):925-931. https://doi.org/10.1126/science.aal0157

Lima AGM (2017) A cultura da batata-doce: cultivo, parentesco e ritual entre os Krahô. Mana 23(2):455-490. https://doi.org/10.1590/1678-49442017v23n2p455

Liu Q, Meng X, Li Y et al (2017) Antibacterial and antifungal activities of spices. Int J Mol Sci 18(6):1283. https://doi.org/10.3390/ijms 18061283

Lorenzi H, Matos FJA (2008) Plantas medicinais no Brasil: nativas e exóticas. Instituto Plantarum, Nova Odessa

Lorenzi H, Moreira de Souza H, Medeiros-Costa JD et al (2004) Palmeiras brasileiras e exóticas cultivadas. Instituto Plantarum, Nova Odessa

Lorenzi H, Lacerda MTC, Bacher LB (2015) Frutas no Brasil: nativas e exóticas - de consumo in natura. Instituto Plantarum de estudos da Flora, São Paulo

Martins OS (2005) Dinâmica evolutiva em roças de caboclos amazônicos. Diversidade Biológica e Cultura da Amazônia. Estudos avançados 19(53):209-220. https://doi.org/10.1590/ S0103-40142005000100013

Martius KV (1979) Natureza, doenças, medicina e remédios dos indíos brasileiros. Brasiliana v 154. Editora Nacional, São Paulo

McMichael CH, Palace MW, Bush MB et al (2013) Predicting pre-Columbian anthropogenic soils in Amazonia. Proc R Soc B 281(20132475):1-10. https://doi.org/10.1098/rspb.2013.2475

Mitchell JD, Daly DC (1998) The "tortoise's cajá"- a new species of Spondias (Anacardiaceae) from southwestern Amazonia. Brittonia 50:447-451. https://doi.org/10.2307/2807753 
Monteiro MHDA, Andreata RHP, Neves LJ (2007) Estruturas secretoras em Sapotaceae. Pesquisas, Botânica 58:253-262

Mori AS, Prance GT (1981) The "sapucaya” group of Lecythis (Lecythidaceae). Brittonia 33:70-80

Muniz J, Molina AR, Muniz J (2015) Physalis: panorama produtivo e econômico no Brasil. Hortic Bras 33(2). https://doi.org/10.1590/S0102-053620150000200023

Nascimento Filho HR, Barbosa RI, Luz FJF (2007) Pimentas do gênero Capsicum cultivadas em Roraima, Amazônia brasileira. Hábitos e formas de uso. Acta Amazônica 37(4):561-568. https://doi.org/10.1590/S0044-59672007000400011

Nelson BN, Oliveira A (2001) Estado do conhecimento florístico da Amazônia. In: Capobianco JPR, Veríssimo A, Moreira A et al (ed) Biodiversidade na Amazônia Brasileira: avaliação e ações prioritárias para a conservação, uso sustentável e repartição de benefícios. São Paulo, pp 132-182

Nimuendaju C (2017) Mapa etno-histórico do Brasil e regiões adjacentes. IPHAN, IBGE, Brasília

Oliveira MSP, Carvalho JEU, Nascimento WMO et al (2002) Cultivo do Açaizeiro para Produção de Frutos. Circular Técnica. Embrapa Amazônia Oriental, Belém

Paul JHA, Seaforth CE, Tikasingh T (2011) Eryngium foetidum L. a review. Fitoterapia 82(3):302308. https://doi.org/10.1016/j.fitote.2010.11.010

Pedrosa HC, Clement CR, Schietti J (2018) The domestication of the Amazon tree grape (Pourouma cecropiifolia) under an ecological lens. Front Plant Sci 9(203):1-14. https://doi.org/10.3389/ fpls.2018.00203

Pereira N (1974) Panorama da alimentação indígena. comidas, bebidas e tóxicos na Amazônia Brasileira. Livraria São José, Rio de Janeiro

Peres LG, Brandão VB, Rezende AJ (2018) Teobromina, substância encontrada no cacau. Revista JRG de Estudos Acadêmicos 1(3):2595-1661

Prance GT (1973) Phytogeographic support for the theory of Pleistocene forest refuges in the Amazon basin, based on evidence from distribution patterns in Caryocaraceae, Chrysobalanaceae, Dichapetalaceae and Lecythidaceae. Acta Amazônica 3:5-28. https://doi. org/10.1590/1809-43921973033005

Prance GT (1975) Estudos sobre a vegetação das Campinas Amazônicas: Introdução a uma série de publicações sobre a vegetação das Campinas Amazônicas. Acta Amazon 5(3):207-209. https://doi.org/10.1590/1809-43921975053207

Rabelo A (2012) Frutos nativos da Amazônia: comercialização nas feiras de Manaus AM. INPA, Manaus

Rangel PHR, Dias T (2016) Reintrodução de variedades tradicionais de arroz para o resgate do sistema de produção diversificado e sustentável dos índios krahô. In: Dias T, Edit JS, Udry C (eds) Diálogos de saberes: coleção povos e comunidades tradicionais, vol 2. Embrapa, Brasília, pp 63-72

Ratsch C (2011) Las plantas del amor, los afrodisíacos en los mitos, la história ay el presente. FCE, México

Rego LJS, Silva ML, Silva LF et al (2017) Caracterização do consumo de amêndoa de cumaru na Amazônia Oriental. Biota Amazônia 7(3):23-27

Ribeiro B (1995) Os índios das águas pretas. Edusp/Companhia das Letras, São Paulo

Ribeiro RG (2018) Estudo etnobotânico e físico-químico da batata-mairá (Casimirella spp. Icacinaceae). Dissertation, Ciências Biológicas, Instituto Nacional de Pesquisas da Amazônia

Ribeiro CSC, Lopes CA, Carvalho SIC et al (2008) Pimentas Capsicum. Embrapa, Brasília

Rodriguez-Amaya DB, Kimura M, Amaya-Farfan J (2008) Fontes brasileiras de carotenóides: tabela brasileira de composição de carotenóides em alimentos. MMA/SBF, Brasília

Roman ALC, Ming LC, Sablayrolles MGP (2000) Pimentas Capsicum L. no Brasil: notas sobre botânica, história, concepções indígenas e folclore. SBEE, Porto Alegre

Roosevelt AC, Costa ML, Machado CL et al (1996) Paleoindian Cave Dwellers in the Amazon: the peopling of the Americas. Science 272(5260):373-384. https://doi.org/10.1126/ science. 272.5260 .373 
Santos GM, Maia GA, Sousa PHM et al (2008) Correlação entre atividade antioxidantes e composição de polpas comerciais de ação (Euterpe oleracea Mart.). Acrhivos latino-americanos de nutricion 58(2):2008

Schultes RE, Hofmann A (2001) Plants of the gods: their sacred, healing and hallucinogenic powers. Inner Traditions

Shanley P, Serra M, Medina G (2010). Frutíferas e plantas úteis na vida amazônica. CIFOR

Shepard G Jr, Ramirez H (2011) "Made in Brazil": human dispersal of the Brazil Nut (Bertholletia excelsa, Lecythidaceae) in Ancient Amazonia. Econ Bot 65(1):44-65. https://doi.org/10.1007/ s12231-011-9151-6

Sibbr (2020) Biodiversidade e nutrição. Sistema de Informação sobre a biodiversidade brasileira. Availabre in https://ferramentas.sibbr.gov.br/ficha/bin/view/FN. Accessed 25 Oct 2020

Silva Filho DF, Noda H, Clement CR (1993) Genetic variability of economic characters in 30 accessions of cubiu (Solanum sessiliflorum Dunal) evaluated in Central Amazonia. Revista Brasileira de Genética 16(2):409-417

Silva LE, Reis RA, Moura EA et al (2015) Plantas do Gênero Xylopia: composição química e potencial farmacológico. Revista Brasileira de Plantas Medicinais 17(4):814-826. https://doi. org/10.1590/1983-084X/14_076

Silva AL, Garcia A, Baniwa AF et al (2016) Pimenta jiquitaia Baniwa. Instituto Socioambiental/ OIBI, São Paulo/São Gabriel da Cachoeira

Simões CMO, Schenkel OS, Mello JCP et al (2017) Farmagnosia do produto natural ao medicamento. Artmed, Porto Alegre

Sivieiro A, Mattar EPC, Silva VB et al (2016) Feijão-comum e feijão-caupi cultivados nas comunidades ribeirinhas e indígenas do Acre. P. In: Dias T, Edit JS, Udry C (eds) Diálogos de saberes - relatos da Embrapa. Coleção povos e comunidades tradicionais, vol 2. Embrapa, Brasília, pp 247-259

Souza MAD (2015) Estudos em Eugenia L. (Myrtaceae) na Amazônia Central: taxonomia com o uso de ferramentas morfoanatômica. Dissertation, Faculdade de Ciências Biológicas, Instituto Nacional de Pesquisas da Amazônia

Spruce R (1851) Journal of a Voyage up the Amazon and Rio Negro. In: Hooker W, Hooker's J (eds) Journal of Botany and Kew Garden Miscellany, Londres, pp 210-212

Stradelli E (1929) Vocabularios da lingua geral portuguez-nheengatú e nheengatú-portuguez, precedidos de um esboço de grammatica nheênga-umbuêsáua mirî e seguidos de contos em lingua geral nheengatú poranduua. Revista do Instituto Histórico e Geográfico Brasileiro 158(104):9-768

Suassuna TMF, Matos RG, Freita FO (2016) Caracterização de variedades de amendoim provenientes do Parque Nacional do Xingu. In: Dias T, Edit JS, Udry C (eds) Diálogos de saberes relatos da Embrapa. Coleção povos e comunidades tradicionais, vol 2. Embrapa, Brasília, pp 145-157

Teixeira FF, Landau EC (2016). Identificação de acesso de milho de origem indígena em banco de germoplasma. In: Dias T, Edit JS, Udry C (eds) Diálogos de saberes - relatos da Embrapa. Coleção povos e comunidades tradicionais, vol 2. Embrapa, Brasília, pp 53-61

Ter Steege H, Vaessen RW, Cárdenas-López D et al (2013) The discovery of the Amazonian tree flora with an updated checklist of all known tree taxa. Nat Sci Rep 6(29549):1-15. https://doi. org/10.1038/srep29549

Ter Steege H, Vaessen RW, Cárdenas-López D et al (2016) A descoberta da flora arbórea da Amazônia com uma lista atualizada de todos os taxa arbóres conhecidos. Boletim Museu Paraense Emílio Goeldi Ciências Naturais 11(2):231-261. https://doi.org/10.1038/srep29549

Tomchinsky B (2017) Prospecção de plantas aromáticas e condimentares no Brasil. Dissertation, Faculdade de Ciências Agronômicas, Universidade Estadual Paulista

Tomchinsky B, Ming LC (2019) As plantas comestíveis no Brasil dos séculos XVI e XVII segundo relatos de época. Rodriguésia 70(e03792017):1-16. https://doi. org/10.1590/2175-7860201970040 
Tomchinsky B, Ming LC, Hidalgo AF et al (2013) Impactos da legislação na pesquisa etnobotânica no brasil, com ênfase na região amazônica. Amazônica. Revista de Antropologia 5(3):734-761. https://doi.org/10.18542/amazonica.v5i3.1603

Trajano AAL (2008) Brasil a gosto. São Paulo, Melhoramentos

Tricaud S, Pinton F, Pereira JS (2016) Saberes e práticas locais do produtores de guaraná (Paullinia cupana Junth var. sorbilis) do médio Amazpnas: dias organizações locais frenta a inovação. Boletim do Museu Paranense Emílio Goeldi Ciências humanas 11(1):33-53. https://doi.org/10 $.1590 / 1981.81222016000100004$

WWF (2017) Novas espécies de vertebrados e plantas na Amazônia: atualização e composição da lista: 2014-2015. WWF-Brasil /instituto de desenvolvimento sustentável Mamirauá, WWFBrasil, Brasíli

Yuyama K, Aguiar JPL, Yuyama LKO (2002) Camu-camu: um fruto fantástico como fonte de vitamina C. Acta Amazon 32(1):169-174. https://doi.org/10.1590/1809-43922002321174

Yuyama LKO, Yuyama K, Aguiar JPL et al (2013) Fruteiras da Amazônia: potencial nutricional. INPA, Manaus 